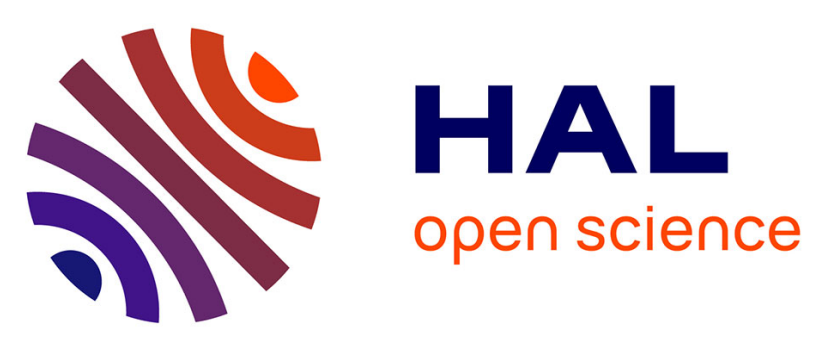

\title{
Minority carriers lifetime degradation during ion implanted silicon solar cell processing
}

\author{
M. Finetti, P. Ostoja, S. Solmi, G. Soncini
}

\section{To cite this version:}

M. Finetti, P. Ostoja, S. Solmi, G. Soncini. Minority carriers lifetime degradation during ion implanted silicon solar cell processing. Revue de Physique Appliquée, 1978, 13 (12), pp.809-813. 10.1051/rphysap:019780013012080900 . jpa-00244551

\section{HAL Id: jpa-00244551 \\ https://hal.science/jpa-00244551}

Submitted on 1 Jan 1978

HAL is a multi-disciplinary open access archive for the deposit and dissemination of scientific research documents, whether they are published or not. The documents may come from teaching and research institutions in France or abroad, or from public or private research centers.
L'archive ouverte pluridisciplinaire HAL, est destinée au dépôt et à la diffusion de documents scientifiques de niveau recherche, publiés ou non, émanant des établissements d'enseignement et de recherche français ou étrangers, des laboratoires publics ou privés. 


\title{
DEFECTS AND CHARACTERIZATION II.
}

\section{MINORITY CARRIERS LIFETIME DEGRADATION DURING ION IMPLANTED SILICON SOLAR CELL PROCESSING (*)}

\author{
M. FINETTI $(* *)$, P. OSTOJA, S. SOLMI and G. SONCINI
}

Laboratorio LAMEL-CNR, Via Castagnoli, 1, 40126 Bologna, Italy

\begin{abstract}
Résumé. - Dans cet article on analyse un procédé de fabrication de photopiles solaires au $\mathrm{Si}$ basé sur l'implantation ionique suivie par un recuit thermique à basse température. On démontre que par l'utilisation de la technique du photovoltage de surface, la dégradation de la durée de vie de la base peut être presque complètement évitée ; c'est pourquoi il est possible de construire des cellules solaires avec un rendement élevé de conversion.
\end{abstract}

\begin{abstract}
In this work a silicon solar cell fabrication process based on ion implantation followed by low temperature thermal annealing is analysed. It is shown, by using the surface photovoltage technique, that the base lifetime degradation can be almost completely avoided, so that ion implanted solar cells with high conversion efficiency can be fabricated.
\end{abstract}

1. Introduction. - Ion implantation technology compares favourably to standard thermal diffusion as a technique suitable for silicon solar cells large scale production, since it allows a simpler fabrication with drastic reduction of the wet processing steps, and consequently higher production yield, higher automation level and lower cost $[1,2]$. With regard to this point it sufficies to observe that the ion implanted solar cell fabrication process simply consists in sequentially implanting a thin $\mathrm{n}^{+}$front layer and a $\mathrm{p}^{+}$ back layer within standard p-type silicon slices. These are then automatically coin-stacked and heat-treated in an inert atmosphere to anneal out the radiation damage and to form the front shallow junction and the back contact field. Finally, metal contacts and the antireflection coating are formed in a standard way to complete the device. In our laboratory ion implantation has been regarded as a technique potentially suitable to define a low temperature fabrication process which could have as main advantage the avoidance of base lifetime degradation that is instead usually produced by the high temperature heat-treatments needed when standard diffusion is used. If the radiation damage can be recovered by low temperature postimplantation annealing, there is in fact a real possibility to keep the base lifetime high by starting with high lifetime material. To this purpose, the surface photovoltage method, initially set up as a standard technique for lifetime control of silicon slices, has been extended to become a non destructive technique for monitoring the minority carrier lifetime within the semiconductor crystal during all the solar cell processing, from the starting slice to the finished device. In this way it becomes possible to optimize the main processing steps and to define a simple and inexpensive solar cell fabrication procedure.

$\left(^{*}\right)$ Work partially supported by the European Economic Community under contract $n^{\circ}$ 195-76-7 ESI.

$\left({ }^{* *}\right)$ Istituto Chimico-Facoltà di Ingegneria-Università di Bologna.
2. Surface photovoltage. - The surface photovoltage (SPV) technique represents a non destructive method particularly attractive to measure minority carrier diffusion length in silicon slices intended for solar cell fabrication, because the physical, phenomenon used in the measurement is the same as that leading to solar cell power production, i.e. the collection of photogenerated minority carriers at the surface space charge layer.

The experimental arrangement set up in our laboratory is shown schematically in figure 1 . A mechanically chopped light beam of known wavelength enters the silicon slice, thus creating hole-electron pairs in the semiconductor bulk, whose generation rate $v s$ depth follows a simple exponential decay law. The electrons generated within the p-type silicon diffuse towards the front surface, and the resultant photovoltage is fed into a lock-in amplifier, whose output drives a digital voltmeter. A small fraction of the incident beam is deflected on a silicon solar cell

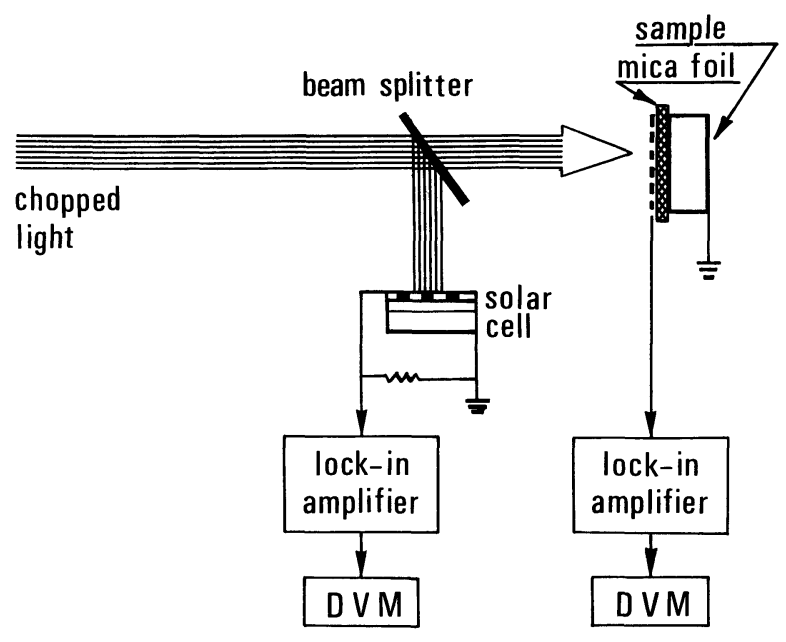

FIG. 1. - Schematic representation of the surface photovoltage (SPV) measurement set-up. 
of known absolute spectral response, which allows an easy monitorage of the incident light intensity.

The measurements are carried out at wavelengths higher than $0.8 \mu \mathrm{m}$, which correspond to a light penetration depth longer than $10 \mu \mathrm{m}$, while light intensity is chosen small enough so that the number of excess minority carriers generated is much smaller than the bulk majority carriers concentration. In this condition the two main theoretical restrictions imposed on the measurement technique, i.e. to minimize the front surface recombination velocity and to operate in low injection conditions, are satisfied.

The linear relationship $[3,4]$

$$
F=K\left(V_{\mathrm{SPV}}\right)\left[\alpha(\lambda)^{-1}-L_{\mathrm{D}}\right]
$$

holds between the flux $F$ of the monochromatic photons entering into the silicon crystal and the reciprocal of the optical absorption coefficient $\alpha(\lambda)$ at that wavelength. The $K$ parameter is a function of the surface photovoltage $V_{\mathrm{SPV}}$. The measurement sequence is as follows : the monochromatic light intensity is adjusted to produce the same photovoltage at various wavelengths within the $0.8<\lambda<1.05 \mu \mathrm{m}$ range. The corresponding photon flux is calculated and plotted against the reciprocal absorption coefficient for each wavelength. The resultant linear plot is extrapolated to zero intensity and the intercept value represents the minority carriers diffusion length $L_{\mathbf{D}}$.

In carrying out these measurements care must be given to avoid stray capacitance effects. To this purpose a special specimen holder has been designed, where the transparent front contact is constituted by a very thin perforated flat metal sheet with an optical transparency of about $50 \%$. A $50 \mu \mathrm{m}$ thick mica foil is used as dielectric to separate the front electrode from the specimen front surface, while the back surface is kept in ohmic contact with the back electrode of the slice holder.

Obviously, the SPV technique can be applied to measure minority carriers diffusion length after the shallow junction formation procedure [4]. In this case the photogenerated electrons are collected by the implanted or diffused $n^{+}-p$ junction.

Finally, the SPV technique has been recently extended to the diffusion length measurement within the base of completed solar cells : in this latter case measurements are carried out by adjusting the monochromatic light intensity to produce the same short circuit current at each wavelength [6]. It can be easily demonstrated by elementary solar cell theory that the linear relationship between incident photon flux and reciprocal absorption coefficient holds also in this case.

The usefulness of the SPV method becomes therefore quite evident : it provides a means to non destructively measure the minority carriers diffusion length after each main technological stage required to produce the completed solar cell, thus allowing both the quality check of the silicon crystal starting material and the continuous control of the fabrication process with respect to this fundamental parameter.

3. Experimental results. - The electron lifetime degradation within the silicon substrate due to the ion implantation process and subsequent thermal annealing has been analysed in detail by the SPV technique. Boron doped $1 \Omega . \mathrm{cm} \mathrm{Si}$ slices have been used in our experiments.

To form the shallow front junction required by the solar cell, $2 \times 10^{15} \mathrm{~cm}^{-2}, 150 \mathrm{keV}$ phosphorus ions have been implanted through $0.15 \mu \mathrm{m}$ thick R.F. sputtered oxide. In this way the doping profile reaches its maximum value nearly at the oxide-silicon interface, thus allowing a low resistance ohmic grid contact to be formed on the silicon front surface.

To form the back surface field, a moderate dose of $280 \mathrm{keV}$ argon ions has been implanted before the boron implant in order to pre-damage the silicon crystal and to avoid the boron reverse annealing effects [7]. Standard $900^{\circ} \mathrm{C}, 30 \mathrm{~min}$ thermal annealing in an inert atmosphere has been applied to these samples to recover the crystallographic radiation damage and to move the implanted dose into electrically active sites. In this case however a strong reduction of the semiconductor lifetime down to values of the order of $1 \mu \mathrm{s}$ or less is consistently observed, which causes a poor collection of the photogenerated carriers within the base and consequently a low conversion efficiency of the finished solar cell. To overcome this difficulty, a systematic analysis of the radiation damage nature and evolution during isochronal thermal annealing of the phosphorus implanted layer as well as of its electrical characteristics has been carried out [8]. The main results of this investigation are summarized in figure 2 , which shows the phosphorus doping profile after $30 \mathrm{~min}$ thermal activation of the implanted dose carried out at different temperatures ranging from $550^{\circ} \mathrm{C}$ up to $900^{\circ} \mathrm{C}$. These experimental data, obtained by the incremental sheet resistance and Hall effect measurement technique [9], demonstrate that in $\langle 100\rangle$ oriented silicon an almost complete electrical activation of the implanted dose is reached, at temperatures as low as $500^{\circ} \mathrm{C}$, while measurements of dark current-voltage characteristics show that at least $750^{\circ} \mathrm{C}$ is needed to produce good quality junctions. A combined proton back-scattering and transmission electron microscopy analysis of the radiation damage evolution during isochronal thermal annealing shows that the high density of amorphous regions from 20 to $30 \AA$ diameter initially present within the implanted region turns into dislocation microloops which increase in diameter by increasing the annealing temperature till about $400 \AA$ between 750 and $900{ }^{\circ} \mathrm{C}$. After this heat treatment, the residual crystallographic radiation damage mainly consists of dislocation loops 


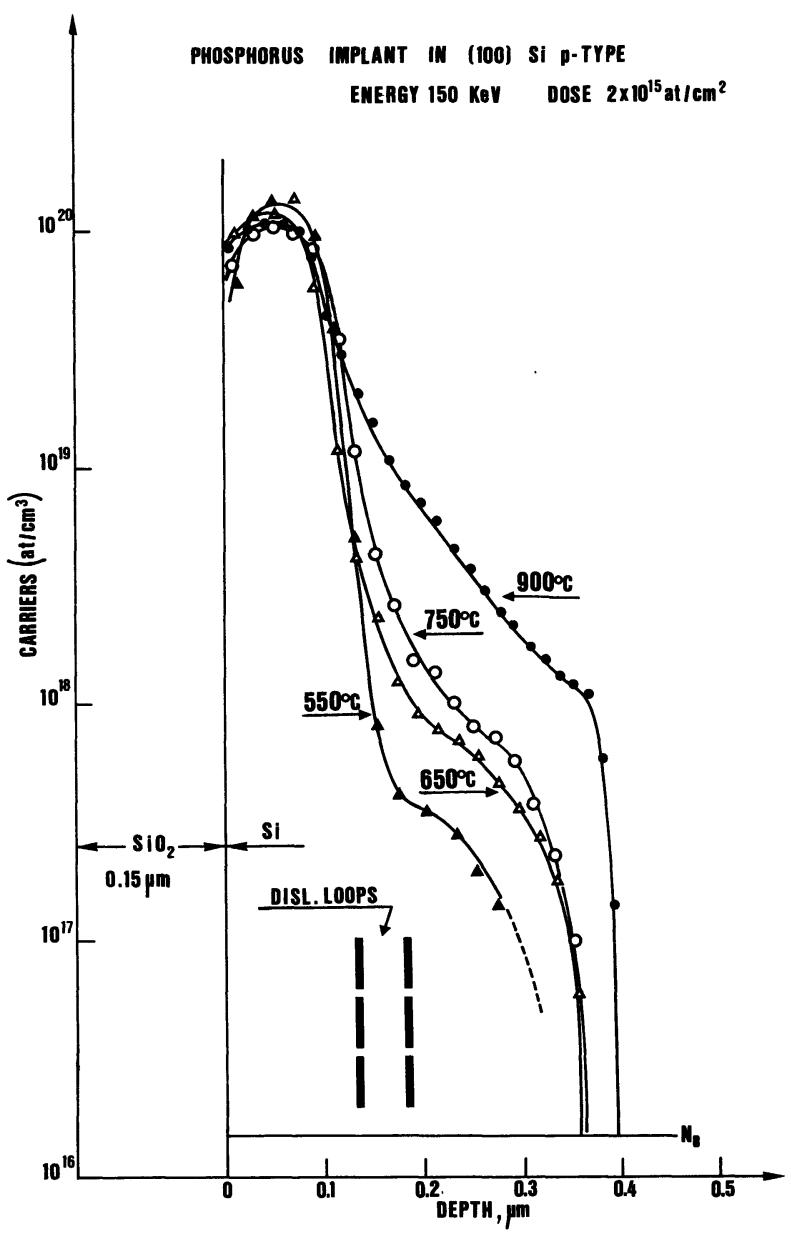

FIG. 2. - Phosphorus concentration profiles after $30 \mathrm{~min}$. thermal annealing carried out in inert atmosphere at different temperatures. The thin region of residual radiation damage is also shown.

clustered in a thin layer from 300 to $500 \AA$ thick approximately $0.15 \mu \mathrm{m}$ below the silicon front surface. Furthermore, experimental Hall-mobility values plotted $v s$ dopant concentration demonstrate, as shown in figure 3 , that the increase of annealing temperature between 750 and $900^{\circ} \mathrm{C}$ allows the carriers mobility within the phosphorus implanted region to approach its normal value found in the bulk with the same doping level [10]. These experimental results suggest that the post-implantation annealing temperatures can be reduced from the usual $900{ }^{\circ} \mathrm{C}$ down to $750^{\circ} \mathrm{C}$ without significatively deteriorate the electrical as well as crystallographic characteristics of the phosphorus implanted region. In this way the base lifetime degradation is strongly reduced, as shown in figure 4 which refers to SPV plots of silicon slices which underwent the same ion implantation process followed by a thermal recovery at $750{ }^{\circ} \mathrm{C}$ and $900{ }^{\circ} \mathrm{C}$ respectively. The higher base lifetime of the $750^{\circ} \mathrm{C}$ annealed sample reflects itself in an improved collection efficiency at long wavelengths, as evidentiated by the measured absolute spectral response of our samples shown in figure 5 . These experimental data

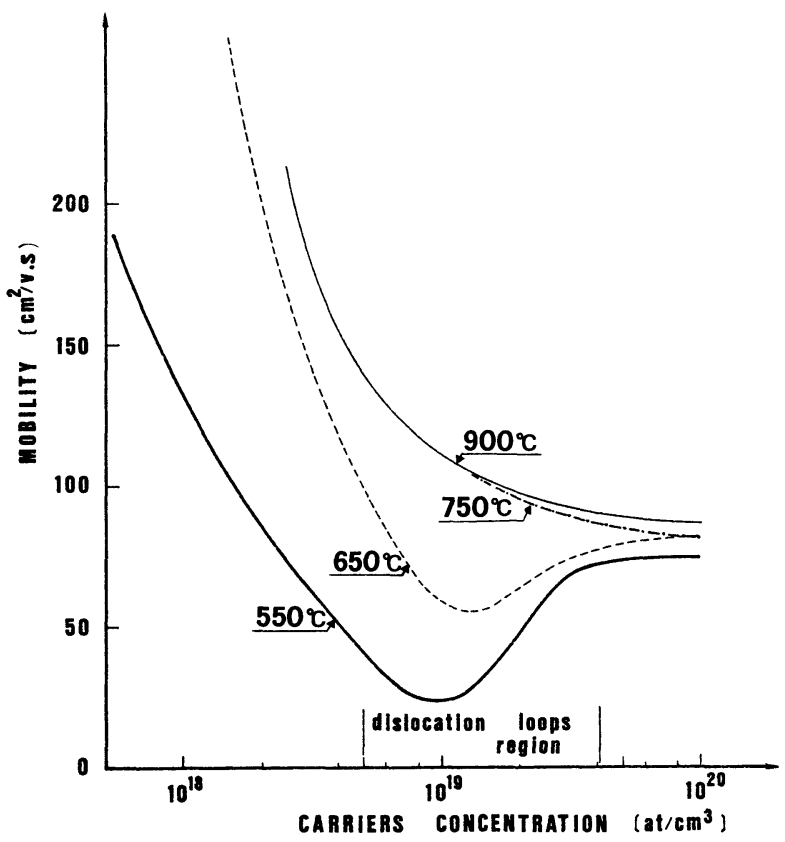

FIG. 3. - Carriers mobility within the phosphorus implanted layer for different annealing temperatures.

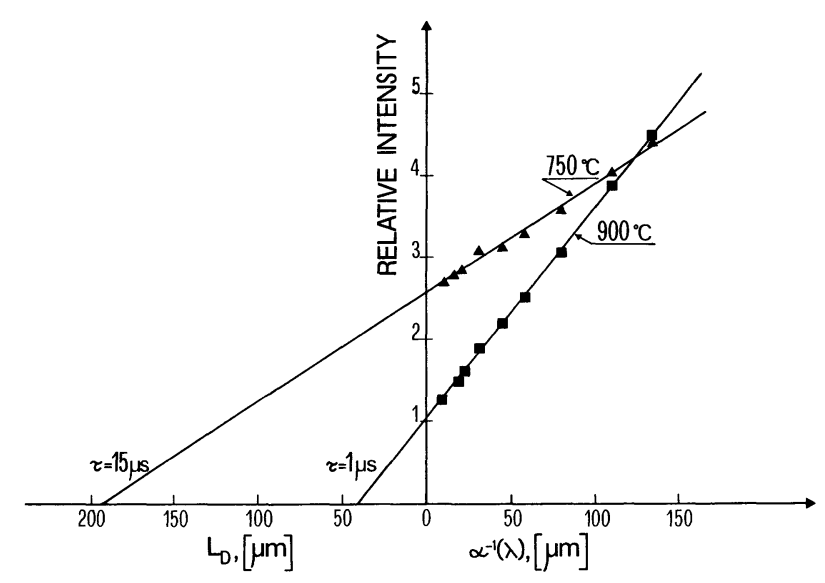

Fig. 4. - SPV plots for ion implanted silicon slices annealed at $750{ }^{\circ} \mathrm{C}$ and $900{ }^{\circ} \mathrm{C}$.

have been analysed by using a computer code which simulates the solar cell behaviour under monochromatic illumination [11]. Calculations have been carried out by hypotizing a base lifetime of 1 and $15 \mu \mathrm{s}$ for our samples, while a surface recombination velocity of $10^{5} \mathrm{~cm} \cdot \mathrm{s}^{-1}$ and an average lifetime of $500 \mathrm{ps}$ have been considered for the phosphorus implanted front layer. The very satisfactory fitting between theory and experiments confirms the lifetime values obtained by the SPV technique. Therefore, the $30 \mathrm{~min}$ $750^{\circ} \mathrm{C}$ post-implantation annealing seems the best compromise between satisfactory electrical characteristics of the $\mathrm{n}^{+}$implanted region and high lifetime in the p-type substrate. 


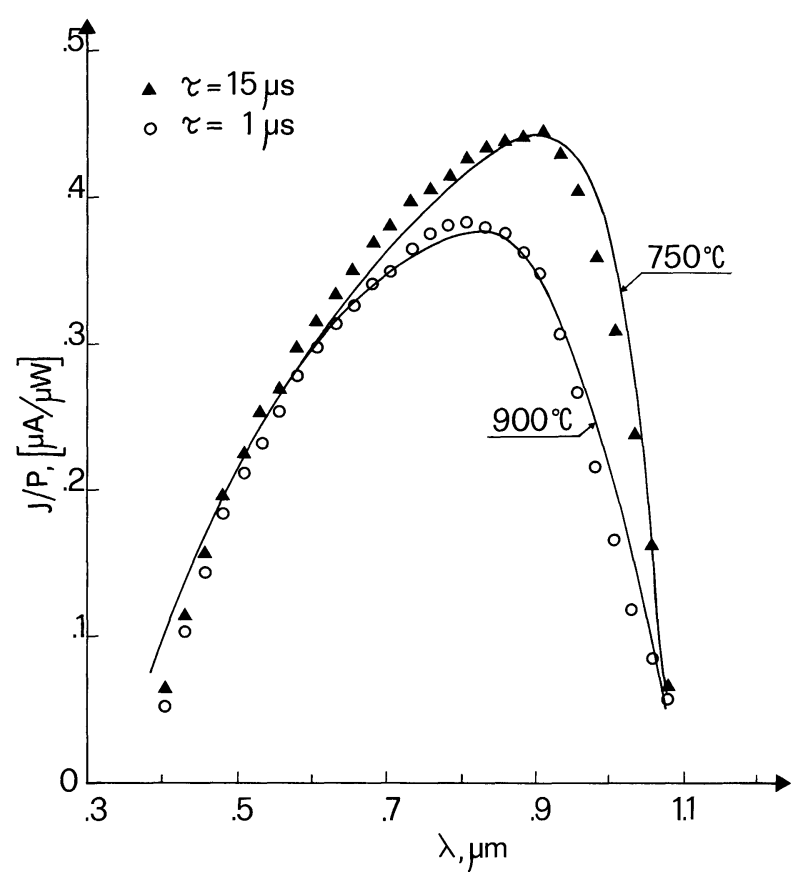

FIG. 5. - Absolute spectral response of $750^{\circ} \mathrm{C}$ and $900{ }^{\circ} \mathrm{C}$ annealed solar cells without antireflection coating.

4. Low temperature ion implanted solar cell fabrication. - By taking into account the experimental results outlined in the previous section it has been possible to define a low temperature fabrication process for phosphorus implanted silicon solar cells. This fabrication process is outlined in figure 6 . The starting material is $1 \Omega \mathrm{cm}$ p-type electronic grade silicon. $\langle 100\rangle$ orientation is preferred, since electrical activity of the implanted dose is reached at lower annealing temperatures with respect to other standard orientations [8], and also lends itself for anti-reflection etching [12].

The minority carriers lifetime within the silicon

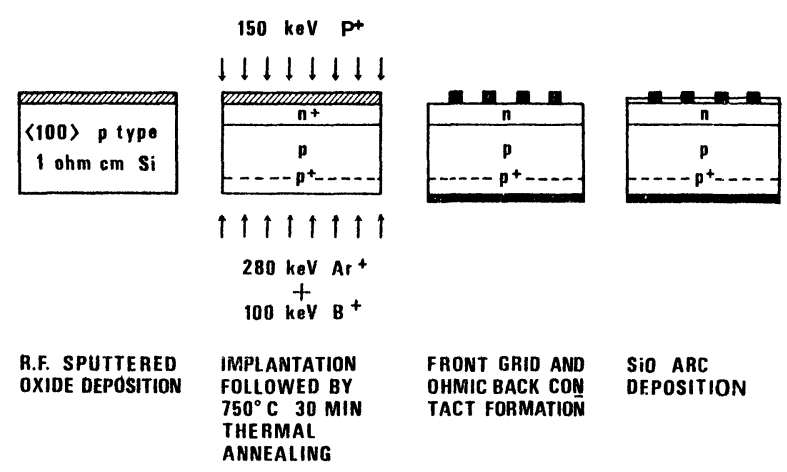

FIG. 6. - Ion implanted silicon solar cells fabrication process. substrate has been measured after each main technological stage required to produce the completed solar cell. Silicon slices both FZ and CZ obtained by two different suppliers have been used in our experiments. Table I summarized the results of these measurements.

It is interesting to observe that lifetime degradation during solar cell processing, caused by thermal recovery of the radiation damage, more severely affects the starting silicon slices with the highest lifetime, so that at the end of the overall processing the best solar cells with respect to base minority carriers lifetime, turn out to be usually the ones fabricated by using standard $\mathrm{CZ}$ silicon crystal. It is also evident, from the data reported in table $I$, the recovery of the base lifetime which follows from the $400{ }^{\circ} \mathrm{C}, 30 \mathrm{~min}$ post-metallization heat treatment.

The $2 \times 2 \mathrm{~cm}^{2}$ ion implanted solar cells show a fillfactor of 0.76 and a series resistance, as measured by the Wolf-Ranschenbach technique [13], of about $0.35 \Omega$. The forward dark current-voltage characteristic, exhibits, within the voltage range of main interest between 0.4 and $0.6 \mathrm{~V}$ ) a quality factor of the order of 1.3 , which testifies the satisfactory quality of the shallow implanted junction, whose electrical behaviour is dominated by the current injection term. Under standard AM1 illumination these cells show a short circuit current density $J_{\mathrm{SC}} \simeq 24.5 \mathrm{~mA}$, an open circuit voltage $V_{\mathrm{OC}} \simeq 0.57 \mathrm{~V}$ and an overall conversion efficiency of about $13.5 \%$. These figures can be furtherly improved by optimizing the front grid geometry and the antireflection coating.

5. Conclusions. - The experimental results presented in this work allow us to draw the following general conclusions with respect to ion implantation applicability for silicon solar cell fabrication :

i) it is possible to define a low temperature production process based on ion implantation which avoids significative base lifetime degradation, thus allowing high efficiency silicon solar cells to be fabricated ;

ii) the residual radiation damage within the $\mathrm{n}^{+}$ front layer does not seem to reduce the minority carriers collection efficiency;

iii) a boron implanted back surface field, electrically activated by the same heat treatment needed for the front $\mathrm{n}^{+}$layer activation, can be produced.

Acknowledgments. - Thanks are due to G. Boccafogli, P. De Luca, S. Guerri and P. Negrini for technical assistance.

TABLE I

Lifetimes evolution during solar cell processing

\section{Silicon}

Starting material

After I. I. and $750^{\circ} \mathrm{C}$ annealing

Completed solar cell
FZ (Supplier A)

CZ (Supplier A)

CZ (Supplier B)

$$
\begin{array}{r}
70 \mu \mathrm{s} \\
15 \mu \mathrm{s}
\end{array}
$$$$
18 \mu \mathrm{s}
$$

$47 \mu \mathrm{s}$

$24 \mu \mathrm{s}$ $28 \mu \mathrm{s}$ 


\section{References}

[1] Kirkpatrick, A. R., Minnucci, J. A., Greenwald, A. C., IEEE Trans. Electron. Devices ED 24 (1977) 429.

[2] Laboratorio LAMEL, C.E.E. Research Contract $\mathrm{n}^{\circ}$ 195-76ESI final Report, February 1978.

[3] Goodman, A. M., J. Appl. Phys. 32 (1961) 2550.

[4] Wang, E. Y., Baraona, C. R. and Brandhorst, H. W., J. Electrochem. Soc. 121 (1974) 973.

[5] Coughey, D. M. and Thomas, R. E., Proc. IEEE 55 (1967) 2192.

[6] Stokes, E. D. and Chu, T. L., Appl. Phys. Lett. 30 (1977) 425.

[7] Dearnaley, G., Freeman, J. H., Nelson, R. S. Stephan, J., Ion Implantation (North Holland) 1973.

[8] Zignani, F., Cembali, F., Galloni, R., Pedulli, L.,
SERVIDORI, M., Photov. Solar Energy Conference Luxembourg 27-30 sept. 1977 (Reidel Publishing Co).

[9] Galloni, R., Gavina, G., Lotti, R., Piombini, A., Revue Phys. Appl. 13 (1978) 81.

[10] Finetti, M., Galloni, R., Mazzone, A. M., J. Appl. Phys. (to be published).

[11] Calzolari, P. U. and Mazzone, A. M., Photov. Solar Energy Conference, Luxembourg 27-30 sept. 1977 (Reidel Publishing $\mathrm{Co}$ ).

[12] Restrepo, R. and BACKUS, C. E., IEEE Trans. Electron, Devices ED 23 (1976) 1196.

[13] Wolf, M. and Ranschenbach, H., Adv. Energy Conversion 3 (1963) 455. 